\title{
Thrixspermum merguense (Hook.f.) Kuntze [Orchidaceae: Epidendroideae: Vandeae: Aeridinae] - an addition to the Orchid flora of Mainland India
}

\author{
Khyanjeet Gogoi \\ TOSEHIM, Regional Orchids Germplasm Conservation \& Propagation Centre (Assam Circle), \\ Daisa Bordoloi Nagar, Talap, Tinsukia 786 156, Assam, India \\ E-mail:khyanjeetgogoi@gmail.com
}

[Received 14.11.2018; Revised 21.11.2018; Accepted 22.11.2018; Published 31.12.2018]

\begin{abstract}
Thrixspermum merguense (Hook.f.) Kuntze (Orchidaceae) is reported as a new distributional record to the orchid flora of Mainland India from Assam. A detailed description of the species along with a plate of colour illustrations of habit and dissected floral parts is provided.
\end{abstract}

Key words: Thrixspermum merguense, Orchidaceae, new record, Mainland India.

\section{INTRODUCTION}

During a field trip to the Joypur Reserve Forest in Dibrugarh district of Assam in August 2018, the author collected an epiphytic orchid in its vegetative condition. The orchid was planted at the Regional Orchids Germplasm Conservation and Propagation Centre (Assam Circle), Assam, where it was flowered during October 2018. On the basis of available literature (Hooker 1890; King \& Pantling 1898; Kataki 1986, Seidenfaden 1988; Seidenfaden \& Wood 1992; Pearce \& Cribb 2002; Kumar \& Kumar 2005; Lucksom 2007; Chen et.al. 2009) and critical examination of the flowers, it was identified as Thrixspermum merguense (Hook.f.) Kuntze which is known to occur so far from Andaman Islands, Myanmar, Vietnam, Malaysia, Sumatra, Java, Krakatu, Taiwan and Philippines (Mathew \& Abraham 1996). Hence the present report of its occurrence from Assam forms a new distributional record to the state as well as for the Indian mainland. A detailed description of the taxon with information on the habitat, distribution, phenology etc. along with a plate of colour illustrations has been provided in the present paper. The voucher specimen is deposited in the ASSM Herbarium of Botanical Survey of India at Shillong, Herbarium of the Department of Life Science, Dibrugarh University (DU) and Herbarium of The Orchid Society of Eastern Himalaya (TOSEHIM), Regional Orchid Germplasm Conservation and Propagation Centre (Assam Circle), Assam.

The genus Thrixspermum Lour. (Orchidaceae: Epidendroideae: Vandeae: Aeridinae) comprises of around 100 species distributed widely from the Himalayas to Philippines and tropical Islands of S.W. Pacific (Chen et al. 2009). So far, 16 species are reported from India (Misra 2007; Mainaet al. 1998; Mao et al. 2011; Gogoi 2011, 2018; Gogoi \&Yonzone 2015; Kumar et al. 2017) of which 6 species viz. T. acuminatissimum (Blume) Reichb.f., T. centipede Lour., T. formosanum (Hayata) Schltr., T. musciflorum A.S. Rao \& J. Joseph, T. pygmaeum (King \& Pantl.) Holttum and T. trichoglottis (Hook.f.) Kuntze. occurs in Assam (Gogoi 2018). The present find of Thrixspermum merguense from Joypur Reserve Forest, forms a new record to the state of Assam and also for the Mainland India thereby making the total number of species in Assam increased to seven. 


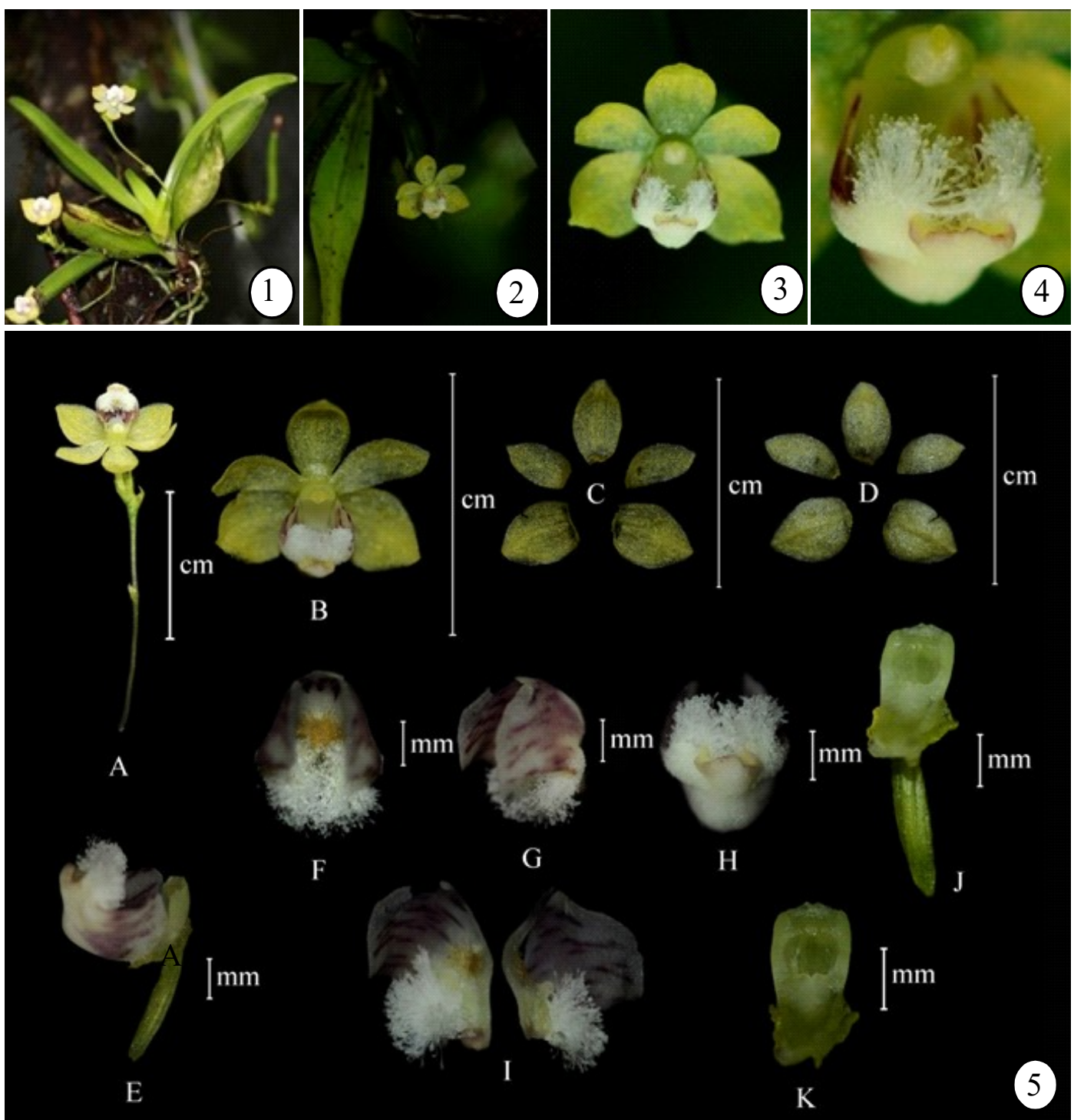

PLATE - I. Thrixspermum merguense (Hook.f.) Kuntze: Figs. 1 - 5: 1. Habit; 2. Flower with inflorescence; 3. Close-up of flower; 4. Close-up of column and lip; 5. Figs. A- K: A. Inflorescence; B. Flower ; C \& D. Perigone, ventral and dorsal views; E. Lip with ovary and column; F, G \& H. Different views of lip; I. Longitudinal section of the lip ; J. Ovary and column; K. Column.

Thrixspermum merguense (Hook.f.) Kuntze, Revis. Gen. P1. 2: 682. 1891; Seidenf. in Opera Bot. 95: 159, f. 97, t. XVI d.1986 \& Opera Bot. 144: 406. 1992; Averyanov in Komarov Bot. Inst. Leningrad 96. 1988; Garnt, Orch. Burma 303. 1895. Sarcochilus merguensis Hook.f., Fl. Brit. India 6: 40. 1890. Dendrocolla merguensis (Hook.f.) Ridl., J. Linn. Soc., Bot. 32: 380. 1896. Thrixspermum comans J.J.Sm., Bull. Dép. Agric. Indes Néerl. 13: 61. 1907. Thrixspermum bicristatum Ames, Orchidaceae 5: 202. 1915. Sarcochilus kusukusensis Hayata, Icon. P1. Formosan. 6: 83. 1916. Thrixspermum kusukusense (Hayata) Schltr., Repert. Spec. Nov. Regni Veg. Beih. 4: 274. 1919. Thrixspermum comans var. bicristatum (Ames) L.O. Williams, Bot. Mus. Leafl. 6: 80. 1938. Ascochilus pulvinatus Guillaumin, Bull. Mus. Natl. Hist. Nat., sér. 2, 36: 539. 1965. [PLATE - I] 
Plants epiphytic; stems $2-3 \mathrm{~cm}$, with several leaves. Leaves nearly basal, lanceolate or elliptic lanceolate, narrowly oblong, $2-6 \times 0.5-0.6 \mathrm{~cm}$, fleshy, apex obtuse and slightly bilobed, sheathing at base, midrib prominent. Inflorescence suberect or ascending, $3.5-5 \mathrm{~cm}$, few flowered; rachis slightly thickened distally; floral bracts not distichous, broadly lanceolate, acute or acuminate, scalelike, $0.2 \times 0.1 \mathrm{~cm}$. Flowers contiguous, opening successively, lasting nearly half a day, yellow, with red stripes on lateral lobes and orange-yellow on midlobe of lip. Dorsal sepal oblong or ovate-oblong, $0.4-0.5 \times 0.2-0.3 \mathrm{~cm}$, obtuse; lateral sepals slightly oblique, similar to but slightly wider than dorsal sepal, obtuse. Petals obovate-oblong, $0.4-0.5$ $\times 0.2-0.3 \mathrm{~cm}$; lip triangular, $0.3 \times 0.5 \mathrm{~cm}$, saccate at base, margin 3-lobed; lateral lobes erect, large, obtuse; mid-lobe $0.1 \times 0.2 \mathrm{~cm}$, truncate; disk with 2 conic calli and 3 tufts of white hairs. Column very short, $0.2 \mathrm{~cm}$, foot short. Pollinia 4, in two pairs.Capsule about transverse to the rachis, $2.5 \mathrm{~cm}$ long, cylindric, linear, striated, with short beak at the apex.

Specimen Examined: Assam, Joypur Reserve Forest, Gogoi 00803, $8^{\text {th }}$ October 2018 [ASSAM, DU, TOSEHIM]

Distribution in India: Assam and Andaman Islands.

General Distribution: India, China, Indonesia, Malaysia, Myanmar, Philippines, Thailand and Vietnam.

Habitat: Epiphytic on tree-main trunks or branches.

Flowering: June - November.

Status: Rare.

\section{Acknowledgements}

The author is thankful to Dr. A. N. Rao for his very useful advices.

\section{LITERATURE CITED}

Chen, X.; Liu, Z.; Zhu, G.; Lang, K.; Ji, Z.; Luo, Y.; Jin, X.; Cribb, P.J.; Wood, J.J.; Gale, S.W.; Ormerod, P.; Vermeulen, J.J.; Wood, H.P.; Clayton, D. \& Bell, A. 2009. Orchidaceae, in Z.Wu, P.H.Raven\&D.Hong (eds), Flora of China, vol. 25. Science Press, Beijing; Missouri Botanical Garden Press, St. Louis, USA.

Gogoi, K. \& Yonzone, R. 2015. Thrixspermum formosanum(Hayata) Schltr. (Orchidaceae) from Karbi Anglong (Assam): A new record for India. The MIOS Journal 16(1): 11-16.

Gogoi, K. 2011. Thrixspermum acuminatissimum(Blume) Reichenbach f. (Orchidaceae) a recollection for India. Pleione 5(2): 334-336.

Gogoi, K. 2018. Wild Orchids of Assam - A Pictorial Guide, Assam State Biodiversity Board, Guwahati, Assam.

Hooker, J.D. 1890. Orchideae. In: Hooker, J.D. (ed.) The Flora of British India, vol. 5. L. Reeve \& Co., London, pp. 667-858.

Kataki, S.K. 1986. Orchids of Meghalaya. Government of Meghalaya, Shillong.

King, G. \& Pantling, R. 1898. The Orchids of the Sikkim-Himalaya. Annal. Royal Bot. Gard., Calcutta 8: $1-342$.

Kumar, C.S. \& Kumar, P.C.S. 2005.An orchid digest of Manipur, North Eastern India. Rheedea 15(1): 1 - 70 . 
Kumar, V.; Verma, D \& Rao A.N. 2017. Thrixspermum indicum (Orchidaceae), a new species from Northeast India. Phytotaxa. 292 (1): 79-84.

Lucksom, S.Z. 2007.The Orchids of Sikkim and North East Himalaya: Development Area, Jiwan Thing Marg, Gangtok, East Sikkim. Pp. 789-791..

Maina, V.; Rao, P.S.N. \& Sinha, B.K. 1998. A new record of Thrixspermum merguense (Hook.f.) Kuntze (Orchidaceae) from Nicobar Islands. J. Bomb. Nat. Hist. Soc. 95(2): $375-376$.

Mao, A.A.; Rao, A.N.; Bhaumik, M. \& Apang, O. 2011. Thrixspermum saruwatarii (Hayata) Schltr. (Orchidaceae) - a new record to India from Arunachal Pradesh. Bull. Arun. For. Res. 26 (1 \& 2): 68 - 70.

Mathew, S.P. \& Abraham, S. 1996. Thrixspermum merguense (Hook.f.) Kze. (Orchidaceae) A new record for the Andaman Islands and Indian flora. Malayan Nat. J. 50: 89 - 91.

Misra, S. 2007. Orchids of India - A glimpse. Bishen Singh and Mahendra Pal Singh, Dehradun.

Pearce, N.R. \& Cribb, P.J. 2002. Flora of Bhutan: The Orchids of Bhutan. Royal Botanic Garden Edinburgh \& Royal Government of Bhutan, Thimpu \& Edinburgh. Pp. 567569

Seidenfaden, G. 1988. Orchid genera in Thailand XIV. Fifty nine vandoid genera. Opera Bot. 95: $148-167$.

Seidenfaden, G. \& Wood, J.J. 1992. The orchids of Peninsular Malaysia and Singapore. Olsen \& Olsen, Fredensborg. 